\title{
ВМІСТ ІНТЕРЛЕЙКИНУ-17А У ХВОРИХ НА АТОПІЧНИЙ ДЕРМАТИТ ЗАЛЕЖНО ВІД СТАТІ ТА ТЯЖКОСТІ ПЕРЕБІГУ ЗАХВОРЮВАННЯ
}

\author{
В.Ю. Мангушева
}

Харківський наиіональний медичний університет, кафедра дерматології, венерології та медичної косметології, м. Харків, Україна, ORCID ID: 0000-0001-5737-6971,e-mail:skinlikar@gmail.com

Резюме. У статті наведено дослідження рівня ІЛ-17А в крові у хворих на атопічний дерматит (АД) залежно від статі та тяжкості перебігу захворювання.

Дослідження вмісту IL-17A виконано у 45 хворих на АД. Жінок - 25 (56\%), які склали I групу. Чоловіків, що увійшли в групу II - 20 (54\%). Середній вік хворих склав $(22,8 \pm 16,6)$ р.

Вміст IL-17А у контрольній групі практично здорових осіб складав у середньому $(13,0 \pm 8,9)$ пг/мл (від 1,3 пг/мл до 27,0 пг/мл) (95 \% ДІ 9,1-16,9 пг/мл).

У хворих на АД він становив від 11,3 до 220,6 пг/мл (у середньому $(113,7 \pm 60,6)$ пг/мл), 95 \% ДІ становив $96,4-130,9$ пг/мл).

При дослідженні АД за шкалою SCORAD тяжкий перебіг визначався у 13(52\%) жінок, хворих АД і склав $(58,4 \pm 14,4)$ балів (від 23,1 до 74,1; $95 \%$ ДІ 48,7-68,1); та у 11 (55\%) чоловіків, хворих АД - $(52,0 \pm 17,8)$

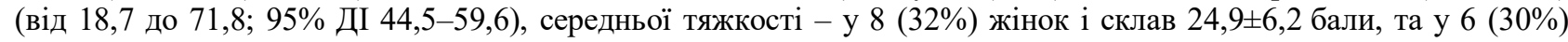
чоловіків і склав $23,7 \pm 8,4$ бали. Легкий перебіг визначався у 4 (15\%) жінок та склав 7,0土1,5 бали, у 4 (15\%) чоловіків склав 6,4 $\pm 3,2$ бали. У чоловіків, хворих на АД вміст IL-17А склав від 19,1 пг/мл до 220,6 пг/мл (у серед-

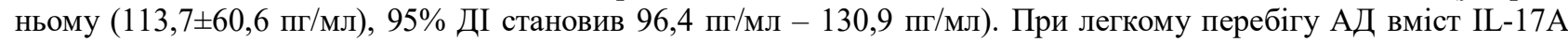
склав $(23,0 \pm 8,9)$ пг/мл, при середньо-важкому перебігу - $(86,8 \pm 48,6)$ пг/мл, а при важкому - $(113,7 \pm 60,6)$ пг/мл ( $<0,001$ за t-критерієм). У жінок при легкому перебігу АД вміст IL-17A склав $(36,0 \pm 60,2)$ пг/мл, при середньоважкому перебігу - $(100,7 \pm 49,7)$ пг/мл, а при важкому - $(179,7 \pm 29,3)$ пг/мл (p<0,001 за t-критерієм).

У жінок, хворих на АД, вміст IL-17А був достовірно вищим, ніж у чоловіків, хворих на АД. Отримані дані підтверджують патогенетичну значимість автоімунних порушень у хворих на АД, одним з клінічних проявів яких є значне збільшення вмісту IL-17A.

Ключові слова: алергодерматози, перебіг захворювання, патологічний процес, імунна відповідь, прозапальний цитокін.

Вступ. Атопічний дерматит виявляється майже у 10-30\% осіб в загальній популяції [1]. Неухильне зростання поширеності алергодерматозів спостерігається й в Україні [2]. У патогенезі АД провідне місце посідають порушення бар'єрної функції шкіри та імунопатологічні реакції [3]. За даними епідеміологічних досліджень, розповсюдженість атопічного дерматиту (АД) серед дітей сягає $20 \%$, серед дорослих - $3 \%$, при цьому в окремих країнах вона зросла у 2-3 рази $[4,5]$.У структурі хронічних дерматозів атопічний дерматит (АД) займає одну з лідируючих позицій, про що свідчить триваюче збільшення поширеності цього дерматозу з більш ніж триразовим його зростанням в порівнянні з 60-ми роками минулого століття. Високий рівень захворюваності АД, його дебют в ранньому віці, безперервно рецидивуючий перебіг патологічного процесу при наявності тенденції до збільшення стійких до традиційної терапії форм, зниження прихильності пацієнтів до лікування надають питанням пошуку причин i вибору раціональної стратегії і тактики терапії цього дерматозу особливої актуальності $[6,7]$. На цей час прийшли до розуміння АД як багатофакторного гетерогенного захворювання, розвиток якого відбувається вна-

слідок поєднаного впливу спадкових факторів і навколишнього середовища $[8,9]$.

Атопічний дерматит виявляється майже у третини осіб в загальній популяції [10] та потребує подальшого детального дослідження.

Обгрунтування дослідження. Головними факторами патогенезу атопічного дерматиту є порушення бар'єрної функції шкіри, алергічна реакція, порушення імунних механізмів і мікробне забруднення, які активуються під впливом алергічних (харчові, побутові, бактеріальні, грибкові та ін.) та неалергічних (забруднення зовнішнього середовища, психоемоційне напруження та ін.) тригерів захворювання $[11$ 12, 13]. Але основним фактором є дисфункція Тклітинної ланки імунної системи 3 переважанням $\mathrm{Th}_{2}$ лімфоцитів [14].

Інтерлейкін-17 (ІЛ-17) - це прозапальний цитокін, який винайдено в 50-х роках минулого століття. Він секретується багатьма клітинами, але найбільш виражену продукцію забезпечують Т-хелпери 17 типу (Th-17), котрі відіграють важливу роль в процесах проліферації кератиноцитів, та беруть участь у багатьох етапах імунної відповіді $[15,16]$. ІЛ17 стимулює продукцію хемокінів i, як наслідок, стимулює міграцію нейтрофілів до місця запалення $[17,18]$. Мішенями для ІЛ-17 є кератиноцити, фібро- 
бласти та епітеліальні клітини [19].

ІЛ-17 вважають одним 3 найважливіших регуляторів природного та адаптивного імунітету в організмі, що особливо проявляється при різних захворюваннях, в тому числі і при атопічному дерматиTi.

Неадекватна імунна відповідь 3 дисциркуляцією імунної толерантності та недостатнє вивчення ролі прозапального цитокіну інтерлейкіну-17 (ІЛ-17) в цих процесах у хворих на атопічний дерматит потребує подальшого детального вивчення.

Мета: дослідити рівень ІЛ-17А в крові у хворих на атопічний дерматит залежно від статі та тяжкості перебігу захворювання.

Матеріали і методи: дослідження вмісту IL17А виконано у 45 хворих на АД. В структурі хворих переважали жінки - 25 (56\%), які склали I групу. Чоловіків, що увійшли в групу II, було - 20 (54\%). Середній вік хворих склав $(22,8 \pm 16,6)$ р. Контрольну групу склали 23 практично здорові особи. Дослідження вмісту IL-17А виконано методом твердофазного аналізу із застосуванням набору реагентів "ИФA-IL-17А”, що містить моноклональні антитіла до IL-17A. Отримані результати були опрацьовані методами математичної статистики 3 використанням пакету PSPP (програмне забезпечення 3 вільним доступом, що не потребує ліцензії) з урахуванням рекомендацій до медико-біологічних досліджень. Для порівняння кількісних показників був використаний t-критерій (Ст'юдента) [20]. Кількісне визначення тяжкості перебігу дерматозу при первинному огляді й у динаміці спостереження за хворими проводилося за системою бальної оцінки ступеня тяжкості АД (індекс SCORAD) [21]. Проводилося визначення й оцінка об'єктивних симптомів, які характеризують інтенсивність шкірного процесу. До них у системі SCORAD віднесені:
1) еритема (гіперемія);
2) набряк / утворення папул;
3) мокнуття / корочки;
4) екскоріації;
5) ліхеніфікація;
6) сухість шкіри.

Ділянки шкіри, які вибиралися для оцінки, були із середньою інтенсивністю кожної з ознак у даного пацієнта, крім ділянок з найбільшим ураженням. Та сама ділянка могла бути обраною для характеристики двох і більше ознак. Сухість визначалася на ділянках без висипок. Кожну ознаку оцінено від 0 до 3 балів (0 - відсутність, 1 - легка вираженість, 2 середня, 3 - важка) відповідно.

Наступним етапом був розрахунок площі ураження шкіри, для якого використовувалося правило «дев' яток», де за одиницю прийнята площа долонної поверхні кисті (одна долоня хворого - 1 \% усієї поверхні шкіри). При цьому бралися до уваги тільки осередки запальних уражень, сухість шкіри не враховувалася. Площу ураженої шкіри виражено у відсотках від усієї поверхні тіла, прийнятої за 100 \%. Половинні оцінки не враховувалися.

Iз суб'єктивних ознак характеризувалися свербіж і порушення сну на підставі середнього сту- пеня їх вираженості протягом останніх трьох днів/ночей за 10-бальною шкалою.

Індекс SCORAD розраховувався за наступною формулою:

$$
\mathrm{SCORAD}=\mathrm{A} / 5+7 \mathrm{~B} / 2+\mathrm{C},
$$

де $\mathrm{A}$ - площа ураженої шкіри, \%;

В - сума балів об'єктивних ознак (еритема, набряк / утворення папул, мокнуття / кірочки, екскоріації, ліхеніфікація та сухість шкіри);

С - сума балів суб’єктивних ознак (свербіж, порушення сну).

Результати дослідження. За результатами статистичного аналізу вміст IL-17А коливався в досить широких межах. У контрольній групі практично здорових осіб він складав у середньому $(13,0 \pm 8,9)$ пг/мл (від 1,3 пг/мЛ до 27,0 пг/мл) (95 \% ДІ 9,1-16,9 пг/мл).

У хворих на АД він становив від 11,3 до 220,6 пг/мл (у середньому $(113,7 \pm 60,6)$ пг/мл), $95 \%$ ДІ становив 96,4-130,9 пг/мл) (табл. 1).

Таблиця 1

Рівень IL-17A в сироватці крові обстежених хворих на початку дослідження

\begin{tabular}{|l|c|c|c|}
\hline \multirow{2}{*}{\multicolumn{1}{|c|}{ Діагно3 }} & \multicolumn{3}{|c|}{ Рівень IL-17А (пг/мл) } \\
\cline { 2 - 4 } & $\mathrm{M} \pm \mathrm{SD}$ & $\begin{array}{c}\text { Нижня } \\
\text { границя }\end{array}$ & $\begin{array}{c}\text { Верхня } \\
\text { границя }\end{array}$ \\
\hline АД (n=45) & $113,7 \pm 60,6^{1}$ & 96,4 & 130,9 \\
\hline $\begin{array}{l}\text { Контрольна } \\
\text { група (n=23) }\end{array}$ & $13,0 \pm 8,9$ & 9,1 & 16,9 \\
\hline
\end{tabular}

Примітка. $^{1}$ - відмінності достовірні порівняно 3 контрольною гупою ( $<<0,05$ за t-критерієм).

При дослідженні рівня IL-17 в залежності від статі, у хворих на АД за шкалою SCORAD тяжкий перебіг визначався у 13 (52\%) жінок, хворих АД і склав $(58,4 \pm 14,4)$ балів (від 23,1 до 74,1; 95\% ДІ 48,7$68,1)$; та у $11(55 \%)$ чоловіків, хворих АД, $(52,0 \pm 17,8)$ (від 18,7 до 71,8; 95\% ДІ 44,5-59,6), перебіг середньої тяжкості визначався у 8 (32\%) жінок і складав 24,9 $\pm 6,2$ бали, та у 6 (30\%) чоловіків і склав $23,7 \pm 8,4$ бали. Легкий перебіг захворювання визнача-

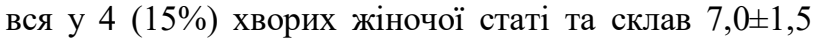
бали, у 4 (15\%) чоловіків цей показник був дещо

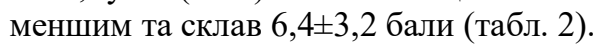

Динаміка тяжкості клінічних проявів АД за шкалою SCORAD залежно від ступеня тяжкості

\begin{tabular}{|l|c|c|}
\hline $\begin{array}{l}\text { Величина } \\
\text { SCORAD }\end{array}$ & $\begin{array}{c}\text { Жінки I } \\
(\mathrm{n}=25)\end{array}$ & $\begin{array}{c}\text { Чоловіки II } \\
(\mathrm{n}=20)\end{array}$ \\
\hline $\begin{array}{l}\text { Тяжкий } \\
\text { перебіг }\end{array}$ & $58,4 \pm 14,4^{1}$ & $52,0 \pm 17,8$ \\
\hline $\begin{array}{l}\text { Середньої } \\
\text { тяжкості }\end{array}$ & $24,9 \pm 6,2^{1}$ & $23,7 \pm 8,4$ \\
\hline Легкий & $7,0 \pm 1,5^{1}$ & $6,4 \pm 3,2$ \\
\hline
\end{tabular}

Примітка. 1 - різниця між I та II групою достовірна $\mathrm{p}<0,05$ за t-критерієм. 
За результатами статистичного аналізу, рівень IL-17A, як у жінок так і у чоловіків, хворих на атопічний дерматит, коливався в досить широких межах.

У осіб чоловічої статі, хворих на АД, він складав від 19,1 пг/мл до 220,6 пг/мл (у середньому

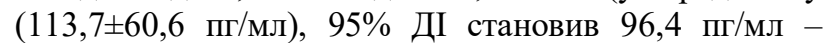
130,9 пг/мл).

При легкому перебігу АД рівень IL-17A складав у середньому $(23,0 \pm 8,9)$ пг/мл. При середньо- важкому перебігу він зростав до $(86,8 \pm 48,6)$ пг/мл, а при важкому сягав $(113,7 \pm 60,6)$ пг/мл $(\mathrm{p}<0,001$ за tкритерієм) (табл. 3).

У осіб жіночої статі при легкому перебігу АД рівень IL-17А складав у середньому $(36,0 \pm 60,2)$ пг/мл. При середньо-важкому перебігу він зростав до $(100,7 \pm 49,7)$ пг/мл, а при важкому сягав $(179,7 \pm 29,3)$ пг/мл (р<0,001 за t-критерієм) (табл. 4).

Рівень IL-17A в сироватці крові чоловіків, хворих на АД

\begin{tabular}{|l|c|c|c|}
\hline \multirow{2}{*}{\multicolumn{1}{|c|}{ Діагно3 }} & \multicolumn{3}{|c|}{ Концентрація IL-17А (пг/мл) } \\
\cline { 2 - 4 } & \multirow{2}{*}{$\mathrm{M} \pm \mathrm{SD}$} & Нижня границя & Верхня границя \\
\cline { 2 - 4 } & $113,7 \pm 60,6$ & 96,4 & 130,9 \\
\hline Тяжкий перебіг $(\mathrm{n}=11)$ & $86,8 \pm 48,6$ & 73,3 & 100,3 \\
\hline Середньої тяжкості(n=6) & $23,0 \pm 8,9$ & 19,1 & 36,9 \\
\hline Легкий перебіг(n=4) & & \\
\hline
\end{tabular}

Таблиця 4

Рівень IL-17A в сироватці крові жінок, хворих на атопічний дерматит

\begin{tabular}{|l|c|c|c|}
\hline \multirow{2}{*}{\multicolumn{1}{|c|}{ Діагноз }} & \multicolumn{3}{|c|}{ Концентрація IL-17А (пг/мл) } \\
\cline { 2 - 4 } & \multirow{2}{*}{$\mathrm{M} \pm \mathrm{SD}$} & Нижня границя & Верхня границя \\
\cline { 3 - 4 } & $179,7 \pm 29,3$ & 160,0 & 199,4 \\
\hline Тяжкий перебіг(n=13) & $100,7 \pm 49,7$ & 79,7 & 121,7 \\
\hline Середньої тяжкості(n=8) & $36,0 \pm 60,2$ & 16,1 & 56,9 \\
\hline Легкий перебіг(n=4) &
\end{tabular}

Обговорення результатів. Дослідженню дисфункції імунної системи, яка спостерігається у хворих на АД, в останні роки присвячено багато досліджень.

Імунну відповідь при АД можна розділити на дві фази - гостру і хронічну. Гостре запалення характеризується підвищеною активністю Тh2 відповіді: експресією IL-4, IL-5 i IL-13, зниженням вироблення інтерферону- $\gamma$ і підвищенням рівня загального і специфічного Ig Е. На противагу цьому хронічне запалення характеризується підвищеною активністю $\mathrm{Th}_{1-}$ відповіді, яка включає збільшення виробництва IL-12 макрофагами й еозинофілами, а також підвищення рівня маркерів хронічного запалення шкіри, таких як IL-5, -8 і інтерферон- $\gamma$. Протизапальні цитокіни IL-4 i -13 спільно 3 IL-5 стимулюють виробництво Ig E i міграцію еозинофілів у осередок запалення. Останнім часом було описано роль нових цитокінів, включаючи IL-16, -17, -21, -22, -23, -27, -31, -33, -35 і тимуса стромального лімфопоетину в імунопатогенезі АД [22]. Сенсибілізація хворих до аероалергенів відбувається через шкіру, для харчових алергенів - через ШКТ, але можлива також через шкіру [23].

За експериментальними та клінічними даними датських дослідників, у хворих на АД із дефіцитом філагрину спостерігається підвищення кількості клітин Th17, які продукують IL-17, у периферичній крові [24].

В данному дослідженні привертає увагу, що незалежно від діагнозу рівень IL-17A у середньому був достовірно більшим, ніж у контрольній групі.
За даними кореляційного аналізу було виявлено пряму залежність вмісту IL-17A та тяжкістю захворювання. Отримані оцінки тяжкості перебігу АД за шкалою SCORAD свідчать, що 50\% чоловіків, що увійшли у дослідження, та $52 \%$ жінок, мали тяжкий перебіг шкірного захворювання.

Показники тяжкості перебігу АД за шкалою SCORAD у жінок були більш виражені, ніж у чоловіків.

У жінок вміст прозапального цитокіну IL17А був достовірно вищим, особливо при тяжкому та середньої тяжкості перебігу захворювання, ніж у хворих чоловічої статі.

Висновки. У хворих на атопічний дерматит під час загострення захворювання спостерігається значне збільшення вмісту прозапального цитокіну IL17А в сироватці крові. Слід зазначити, що у осіб жіночої статі, які увійшли у дослідження, шкірний процес був більш виражений, ніж у чоловіків, а також відмічався більший вміст IL-17А в сироватці крові. Отримані дані підтверджують патогенетичну значимість автоімунних порушень у хворих на АД, та можуть в майбутньому використовуватись для оптимізації лікування та профілактики цих пацієнтів.

\section{References:}

1. Nutten S. Atopic dermatitis: global epidemiology and risk factors. Ann. Nutr. Metab. 2015; 66 (suppl. 1): 8 16. (in English)

2. Volkoslavs'ka VM. Pro dinami 'ku deyakikh pokazniki`v stanu shki rno-venerologi chnoyi dopomogi za 
2000-2015 rr. v Ukrayini`. Dermatologi`ya ta venerologi ya. 2016; 3 (73): 61-68.( in Ukrainian)

3. Rezni kova AO. Oczi'nka i`munologi 'chnikh zmi`n ta alergologi chnikh reakczi j u khvorikh na atopi chnij dermatit ri`znikh vi`kovikh grup. Dermatologi ya ta venerologi ya. 2015; 4 (70): 67-72. (in Ukrainian)

4. Sybilski AJ, Raciborski F, Lipiec A, et al. Atopic dermatitis is a serious health problem in Poland. Epidemiology studies based on the ECAP study. Postep Derm Alergol. 2015; XXXII(1): P. 1-10. (in English)

5. Kim K. Influences of Environmental Chemicals on Atopic Dermatitis. Toxicol. Res. 2015; 31(2): 89-96. doi: 10.5487/TR.2015.31.2.089. (in English)

6. Guarner F, Sanders ME, Eliakim R, Fedorak R, Gangl A, Garisch J, et al. Probiotics and prebiotics. World Gastroenterology Organisation Global Guidelines. February 2017. Abailable on: http://www.worldgastro enterology. org/UserFiles/ file/ guidelines/ probiotics -and-prebiotics-russian -2017.pdf. (in English)

7. Simonova AV, Kosheleva IV, Shady'zheva LI. Optimizacziya lecheniya i profilaktiki obostrenij atopicheskogo dermatita s uchetom osnovny'kh patogeneticheskikh faktorov. Lechashhij vrach. 2016; 5. Dostupno na: http://www.lvrach.ru/2016/05/ 1543 6473. (in Russian)

8. Kalyuzhna LD, Grechans`ka LV. Pi`dkhi`d do rozrobki uni fi'kovanogo kli ni chnogo protokolu $\mathrm{z}$ di agnostiki ta li kuvannya atopi chnogo dermatitu. Ukrayins'kij zhurnal dermatologi yi, venerologi'yi, kosmetologi yi. 2016; 3: 44-46. Rezhim dostupu: http://nbuv.gov.ua/UJRN/Ujdvc_2016_3_9. (in Ukrai nian)

9. Manti S, Chimenz R, Salpietro A, Colavita L, Pennisi P, Pidone C, Sturiale M, et al. Atopic dermatitis: expression of immunological imbalance. J. Biol. Regul. Homeost. Agents. 2015; 29(2) Suppl 1:13-17. (in English).

10. Kanto R, Thysen JP, Pallr AS, Silverbrg JI. Atopic dermatitis, atopic eczema, or eczema? A systematic review, meta-analysis, and recommendation for uniform use of 'atopic dermatitis. Allergy. 2016. doi: 10.1111/all.12982. (in English)

11. Alhabbab R, Blair P, Elgueta R, Stolarczyk E, Marks $\mathrm{E}$, Becker PD, et al. Diversity of gut microflora is required for the generation of $\mathrm{B}$ cell with regulatory properties in a skin graft model. Scientific Reports. 2015; 5, 11554; doi: 10.1038/srep11554 (2015). www.nature.com/ scientificreports. (in English)

12. Heratizadeh A. Atopic dermatitis: new evidence on the role of allergic inflammation. Curr Opin Allergy Clin Immunol. 2016, Aug 4. [Epub ahead of print]. (in English)

13. Simanski M, Harder J, Rademacher F. RNase 7 in Cutaneous Defense. Int. J. Mol. Sci. 2016; 17, art. 560. doi:10.3390/ijms17040560. (in English)

14. Amatia N, Garg AV, Gaffen SL IL-17 Signaling: The Yin and the Yang. IL-17 Signaling: The Yin and the Yang. Trends Immunollogy.2017; 38(5):310-322. doi: 10.1016/j.it.2017.01.006. (in English)

15. Amatia N, Garg AV, Gaffen SL. IL-17 Signaling: The Yin and the Yang. IL-17 Signaling: The Yin and the Yang. Trends Immunollogy.2017; 38(5):310-322. doi: 10.1016/j.it.2017.01.006. (in English)
16. Madhok V, Futamura M, Thomas KS, Barbarot S. What's new in atopic eczema? An analysis of systematic reviews published in 2012 and 2013. Part 1. Epidemiology, mechanisms of disease and methodological issues. Clin Exp Dermatol. 2015; 40(3):238-242. (in English)

17. Tan Q, Yang H, Liu EM, Wang H. Establishing a Role for Interleukin-17 in Atopic Dermatitis-Related Skin Inflammation J Cutan Med Surg. 2017; 21(4):308-315. doi: 10.1177/1203475417697651. (in English)

18. Simanski M, Harder J, Rademacher F. R Nase 7 in Cutaneous Defense. Int. J. Mol. Sci. 2016; 17, art. 560. doi:10.3390/ijms17040560. (in English)

19. Bonefeld CM, Petersen TH, Bandier J, Agerbeck C, Linneberg A, Ross-Hansen K, et al. Epidermal filaggrin deficiency mediates increased systemic $\mathrm{T}$ helper 17 immune response. Br J Dermatol. 2016. DOI: 10.1111/bjd.14570. (in English)

20. Glancz S. Mediko-biologicheskaya statistika. Per. s angl. M., Praktika, 1998; 459 s. (in English)

21. Adaskevich VP. Diagnosticheskie indeksy` v dermatologii. M: Izd-vo Panfilova; BINOM. Laboratoriya Znanij, 2014. 352 s. (in Russian)

22. Stukova EI, Keniksfest YuV. Patogeneticheskoe znachenie zolotistogo stafilokokka pri atopicheskom dermatite. Fundamental'ny`e issledovaniya. 2013; 7 : 680-687. (in Russian)

23. Lee J, Noh G, Lee S, Youn Y, Rhim J. Atopic dermatitis and cytokines: recent patents in immunoregulatory and therapeutic implications of cytokines in atopic dermatitis--part I: cytokines in atopic dermatitis Recent Pat Inflamm. Allergy Drug Discov. 2012; 6(3): 222-247. PMID: 22827753. (in English)

24. Islander U, Andersson A, Lindberg E, Adlerberth I, Wold AE, Rudin A. Superantigenic Staphylococcus aureus Stimulates Production of Interleukin-17 from Memory but Not Naive T Cells. Infection and immunity. 2010; 78(1): 381-386 doi:10.1128/IAI.00724-09. (in English)

\section{УДК 616.521-053.2.085+615.454.1 \\ СОДЕРЖАНИЕ ИНТЕРЛЕЙКИНА-17А У БОЛЬНЫХ АТОПИЧЕСКИМ ДЕРМАТИТОМ В ЗАВИСИМОСТИ ОТ ПОЛА И ТЯЖЕСТИ ЗАБОЛЕВАНИЯ}

\section{В.Ю. Мангушева}

Харьковский нацииональный медицинский университет, кафедра дерматологии, венерологии и медицинской косметологии, г. Харьков, Украина, ORCID ID: 0000-0001-5737-6971, e-mail:skinlikar@gmail.com

Резюме. В статье приведены исследования содержания ИЛ-17А в крови у больных атопическим дерматитом (АД) в зависимости от пола и тяжести течения заболевания.

По результатам статанализа, содержание IL17А в контрольной группе практически здоровых лиц составило $(13,0 \pm 8,9)$ пг/мл (от 1,3 пг/мл до 27,0 
пг/мл) (95 \% ДИ 9,1-16,9 пг/мл).

У больных АД оно составляло от 11,3 до 220,6 пг/мл $(113,7 \pm 60,6)$ пг/мл), 95 \% ДИ составило 96,4-130,9 пг/мл).(таб.1)

Исследование содержания IL-17А выполнено у 45 больных АД: женщин - 25 (56\%), которые составили I группу. Мужчин, вошедших в группу II, - 20 $(54 \%)$. Средний возраст больных составил $(22,8 \pm$ $16,6)$ лет.

При исследовании АД по шкале SCORAD тяжелое течение заболевания определялось у 13 (52\%) женщин, больных АД, и составило $(58,4 \pm 14,4)$ баллов (от 23,1 до 74,1; 95\% ДИ 48,7-68, 1); и у 11 (55\%) мужчин, больных АД, - $(52,0 \pm 17,8)$ (от 18,7 до 71,$8 ; 95 \%$ ДИ 44,5-59,6), средней тяжести - у 8 $(32 \%)$ женщин и составило $24,9 \pm 6,2$ балла, и у 6 $(30 \%)$ мужчин и составило $23,7 \pm 8,4$ балла. Легкое течение заболевания определялось у 4 (15\%) женщин и составило 7,0 $\pm 1,5$ балла, у 4 (15\%) мужчин составило $6,4 \pm 3,2$ балла. У мужчин содержание IL-17A составило от 19,1 пг / мл до 220,6 пг / мл (в среднем (113,7 \pm 60,6 пг / мл), 95\% ДИ составило 96,4 пг / мл - 130,9 пг / мл). При легком течении АД содержание IL-17A составило $(23,0 \pm 8,9)$ пг / мл, при среднетяжелом течении - $(86,8 \pm 48,6)$ пг / мл, а при тяжелом - $(113,7 \pm 60,6)$ пг / мл (p $<0,001$ по t-критерию). $\mathrm{y}$ женщин при легком течении АД содержание IL$17 \mathrm{~A}$ составило $(36,0 \pm 60,2)$ пг / мл, при среднетяжелом течении - $(100,7 \pm 49,7)$ пг / мл, а при тяжелом - $(179,7 \pm 29,3)$ пг / мл (р <0,001 по t-критерию).

У женщин, больных АД, содержание IL-17A было достоверно выше, особенно при тяжелом и средней тяжести течении заболевания, чем у мужчин, больных АД. Полученные данные подтверждают патогенетическую значимость аутоиммунных нарушений у больных АД.

Ключевые слова: алергодерматозы, течение заболевания, патологический процесс, имунный ответ, провоспалительный цитокин.

\section{UDC 616.521-053.2.085+615.454.1 \\ THE CONTENT OF INTERLEYKIN-17A IN PATIENTS WITH ATOPIC DERMATITIS DEPENDING ON THE GENDER AND THE SEVERITY OF THE DISEASE COURSE}

\author{
V.Y. Mangusheva
}

\begin{abstract}
Kharkiv National Medical University, Department of dermatology, venereology and medical cometology, Kharkiv, Ukraine,

ORCID ID: 0000-0001-5737-6971, e-mail:skinlikar@gmail.com
\end{abstract}

Abstract. The article studies the level of IL-17A in the blood of patients with atopic dermatitis (AD) depending on the sex and the severity of the disease.

Materials and methods. The study of the content of IL-17A was conducted in 45 patients with atopic dermatitis. The structure of patients was dominated by women - $25(56 \%)$ who made up Group I. In group II there were 20 men $(54 \%)$. The mean age of the patients was $(22.8 \pm 16.6)$. Studies of the content of IL-17A were performed by solid-phase analysis using a set of reagents IL-17A containing monoclonal antibodies to IL-17A. The results were processed using mathematical statistics using the PSPP package.

Research results. The content of IL-17A in the control group of healthy subjects averaged $(13.0 \pm 8.9)$ $\mathrm{pg} / \mathrm{ml}$ (from $1.3 \mathrm{pg} / \mathrm{ml}$ to $27.0 \mathrm{pg} / \mathrm{ml}$ ) (95\% CI 9.1$16.9 \mathrm{pg} / \mathrm{ml}$ ). In patients with blood pressure, it ranged from 11.3 to $220.6 \mathrm{pg} / \mathrm{ml}($ mean $(113.7 \pm 60.6) \mathrm{pg} / \mathrm{ml})$, 95\% CI was 96.4-130.9 pg / ml).

In the study of atopic dermatitis on the SCORAD scale, the severe course was determined in 13 $(52 \%)$ women with and made $(58.4 \pm 14.4)$ points (from 23.1 to 74.1 ; $95 \%$ CI $48.7-68,1)$; and in $11(55 \%) \mathrm{men}$ with atopic dermatitis - $(52.0 \pm 17.8)$ (from 18.7 to 71.8 ; 95\% CI 44.5-59.6), the course of moderate severity was determined in $8(32 \%)$ of women and made $24,9 \pm 6,2$ points, and $6(30 \%)$ men and made $23,7 \pm 8,4$ points. The mild course of the disease was determined in $4(15 \%)$ female patients and amounted to $7.0 \pm 1.5$ points, in 4 $(15 \%)$ men this indicator was slightly smaller and amounted to $6.4 \pm 3.2$ points. analysis of the level of IL$17 \mathrm{~A}$, both in women and in men with atopic dermatitis, varied widely enough. In male patients with atopic dermatitis, it ranged from $19.1 \mathrm{pg} / \mathrm{ml}$ to $220.6 \mathrm{pg} / \mathrm{ml}$ ( on average $(113.7 \pm 60.6 \mathrm{pg} / \mathrm{ml}), 95 \% \mathrm{CI}$ was $96.4 \mathrm{pg} / \mathrm{ml}$ $130.9 \mathrm{pg} / \mathrm{ml})$.

With mild atopic dermatitis, the level of IL-17A was $(23.0 \pm 8.9) \mathrm{pg} / \mathrm{ml}$. At moderate-to-heavy course, it increased to $(86.8 \pm 48.6) \mathrm{pg} / \mathrm{ml}$, and at severe course reached $(113.7 \pm 60.6) \mathrm{pg} / \mathrm{ml}(\mathrm{p}<0.001$ by t-test $)$. Woman with mild atopic dermatitis, IL-17A level averaged $(36.0 \pm 60.2) \mathrm{pg} / \mathrm{ml}$. At moderate-to-heavy course, it increased to $(100.7 \pm 49.7) \mathrm{pg} / \mathrm{ml}$, and at severe course reached $(179.7 \pm 29.3) \mathrm{pg} / \mathrm{ml}(\mathrm{p}<0.001$ by $\mathrm{t}-$ test).

Conclusions. At present, AD is understood as a multifactorial heterogeneous disease, the development of which is due to the combined influence of hereditary factors and the environment IL-17 is considered one of the most important regulators of natural and adaptive immunity in the body, especially manifested in various diseases, including atopic dermatitis.

Adequate immune response with immune tolerance dyscirculation and insufficient study of the role of the proinflammatory cytokine interleukin-17 (IL-17) in these processes in patients with atopic dermatitis need further detailed study. Obtained estimates of the severity of $\mathrm{AD}$ on the SCORAD scale indicate that $50 \%$ of men who entered the study and $52 \%$ of women had a severe course of skin disease. The severity of $\mathrm{AD}$ on the SCORAD scale in women was more pronounced than in men. In women, the content of the proinflammatory cytokine IL-17A was significantly higher, especially in severe and moderate severity of the disease than in male patients. In patients with atopic dermatitis during exacerbation of the disease there is a significant increase in the content of the proinflammatory cytokine IL-17A in the serum. The data obtained confirm the pathogenetic signif- 
icance of autoimmune disorders in $\mathrm{AD}$ patients and may be used in the future to optimize treatment and prophylaxis in these patients.
Keywords: allergodermatosis, course of disease, pathological process, immune response, proinflammatory cytokine.

Стаття надійшла в редакцію 12.022020 р. 